\title{
Ocena aktywności antyoksydacyjnej ananasa jadalnego (Ananas comosus)
}

\author{
Evaluation of the antioxidant activity of pineapple (Ananas comosus)
}

\author{
Joanna Zielonka-Brzezicka ${ }^{1}$, Anna Nowakㄹ, Adam Klimowicz¹, Wiktoria Duchnik¹, Daria Wira², \\ Daria Wysocka², Karolina Grzesiak², Ewelina Rędzikowska², Laura Synowiec², Barbara Ptak², Joanna Bilska² \\ ${ }^{1}$ Pomorski Uniwersytet Medyczny w Szczecinie, Katedra i Zakład Chemii Kosmetycznej i Farmaceutycznej, al. Powstańców Wlkp. 72, 70-111 Szczecin \\ Pomeranian Medical University in Szczecin, Chair and Department of Cosmetic and Pharmaceutic Chemistry \\ ${ }_{2}^{2}$ Pomorski Uniwersytet Medyczny w Szczecinie, Studenckie Koło Naukowe przy Katedrze i Zakładzie Chemii Kosmetycznej i Farmaceutycznej, \\ al. Powstańców Wlkp. 72, 70-111 Szczecin \\ Pomeranian Medical University in Szczecin, Chair and Department of Cosmetic and Pharmaceutic Chemistry, Student Research Group \\ $\triangle$ joanna.zielonka-brzezicka@pum.edu.pl
}

\begin{abstract}
Introduction: Pineapple is a well-known tropical fruit valued both for its taste and nutritive properties as a source of compounds that positively affect health. The fruit contains vitamins $\mathrm{C}, \mathrm{A}, \mathrm{B}_{1}$, beta-carotene, proteolytic enzymes, sugars as well as antioxidants: flavonoids and polyphenols.

The aim of the study was to evaluate the antioxidant properties of extracts prepared from different parts of the plant.

Materials and methods: The antioxidant activity of extracts of fruit pulp, rosette leaves and the skin were assessed. Ethanol at $70 \%(\mathrm{v} / \mathrm{v})$ and $96 \%(\mathrm{v} / \mathrm{v})$ and methanol at $99.8 \%(\mathrm{v} / \mathrm{v})$ were used as solvents. Ultrasound-assisted extraction was used. To analyze the above-mentioned properties of the extracts, 2,2-diphenyl1-picrylhydrazyl (DPPH), ferric ion reducing antioxidant parameter (FRAP) and Folin-Ciocalteu methods were used.
\end{abstract}

Results: The obtained results suggest that the antioxidant activity of the extracts depended on the part of the fruit from which the extracts were taken as well as the extraction time and applied solvent. Taking into account analyses using DPPH and FRAP methods, the skin and pulp extracts proved to be most active, while in the case of the Folin-Ciocalteu method, the pulp was most active. The most suitable extractant was ethanol at $70 \%(\mathrm{v} / \mathrm{v})$.

Conclusions: The pineapple extracts exhibited moderate antioxidant potential, depending on the part of the plant and solvent used. Despite its rather low activity, it can be used as a helpful nutrient ingredient to maintain good health, owing to other beneficial properties from the content of valuable active ingredients. Keywords: pineapple; DPPH method; FRAP method; Folin-Ciocalteu method; antioxidant activity.

\section{ABSTRAKT}

Wstęp: Ananas jest powszechnie znanym owocem tropikalnym cenionym zarówno ze względu na walory smakowe, jak i właściwości odżywcze, gdyż stanowi źródło związków pozytywnie wpływających na zdrowie. W skład owocu wchodzą witaminy C, A i $B_{1}$, beta-karoten, enzymy proteolityczne, cukry, a także flawonoidy i polifenole, które zaliczane są do szerokiej grupy przeciwutleniaczy.

Celem pracy była ocena właściwości antyoksydacyjnych wyciągów alkoholowych sporządzonych z różnych części rośliny.

Materiały i metody: Ocenie aktywności przeciwutleniającej poddano alkoholowe ekstrakty z owocostanu, liści przykwiatowych i okrywy ananasa jadalnego. Jako rozpuszczalniki użyto $70 \%$ (v/v) i $96 \%$ (v/v) etanol oraz 99,8\% (v/v) metanol. Wykorzystano metodę ekstrakcji wspomaganą ultradźwiękami. Do analizy badanych właściwości ekstraktów posłużyła metoda z użyciem odczynnika 2,2-difenylo-1-pikrylohydrazylu (DPPH), oznaczanie zdolności redukowania jonów żelaza (FRAP) oraz metoda Folina-Ciocalteu.

Wyniki: Działanie przeciwutleniające otrzymanych wyciągów zależne było zarówno od części owocu, z której pozyskano ekstrakty, jak i czasu ekstrakcji oraz rodzaju użytego rozpuszczalnika. W przypadku analiz z użyciem metod DPPH i FRAP najbardziej wartościowe okazały się wyciągi z okrywy i miąższu ananasa jadalnego, natomiast przy oznaczeniu metodą FolinaCiocalteu - z miąższu. Najkorzystniejszym ekstrahentem okazał się $70 \%(\mathrm{v} / \mathrm{v})$ etanol.

Wnioski: Ekstrakty z ananasa jadalnego wykazują umiarkowaną aktywność antyoksydacyjną, zależną od części rośliny oraz zastosowanego rozpuszczalnika. Mimo niewysokich wartości może być on przydatny jako składnik pożywienia pomocny w utrzymaniu dobrego stanu zdrowia z uwagi na inne korzystne właściwości i obecność cennych substancji aktywnych.

Słowa kluczowe: ananas jadalny; metoda DPPH; metoda FRAP; metoda Folina-Ciocalteu; aktywność antyoksydacyjna.

\section{WSTĘP}

Ananas jadalny (Ananas comosus) należy do rodziny bromieliowatych (Bromeliaceae). Jest wieloletnią byliną dorastającą do 0,5-1,5 m wysokości. Charakteryzuje się sztywnymi

i równolegle rozłożonymi mięsisto-włóknistymi liśćmi, które kończą się ostrym i kłującym wierzchołkiem, tworząc rozetę. Owocostan rozwija się z całego kwiatostanu żeńskiego, a jego miąższ, o barwie żółtawo-zielonej do pomarańczowej, ma słodko-kwaśny smak. Główną składową owocu jest woda, 
ale cechuje się on również dużą zawartością cukrów (do 17\% masy), witamin $\mathrm{C}, \mathrm{A}$ i $\mathrm{B}_{1}$, beta-karotenu, flawonoidów oraz polifenoli $[1,2,3]$.

Ananas jest powszechnie znanym owocem, konsumowanym zarówno w formie świeżej, jak i przetworzonej, cenionym przede wszystkim ze względu na przyjemny aromat i smak. Jego światowa produkcja rocznie sięga nawet $19 \mathrm{mln}$ ton [2]. Jest zaliczany do owoców subtropikalnych i występuje powszechnie w Tajlandii, Chinach, Brazylii, Indiach i na Filipinach, dokąd sprowadzony został z Gwadelupy. W warunkach naturalnych dojrzewa w okresie letnim, ale w zmodyfikowanym otoczeniu, poddawany działaniu kwasu naftylooctowego, dojrzewa przez cały rok, dzięki czemu jest powszechnie dostępny [4, 5]. Ananas comosus jest rośliną o wielu korzystnych właściwościach, stosowaną np. w tradycyjnej medycynie chińskiej z uwagi na obecność bioaktywnych związków pozytywnie wpływających na zdrowie. Roślina ta zawiera enzymy mające wspomagać funkcjonowanie układu pokarmowego, może działać przeciwnowotworowo i przeciwwirusowo [6]. Jedną z lepiej poznanych substancji czynnych, których źródłem jest ananas, jest bromelaina. Pozyskuje się ją z łodyg, owoców i liści. Zawiera mieszaninę enzymów proteolitycznych, która znalazła zastosowanie w przemyśle spożywczym, farmaceutycznym, tekstylnym i kosmetycznym [3, 7, 8]. Ma działanie przeciwzapalne, zmniejsza ból u pacjentów z artretyzmem, redukuje ryzyko tworzenia blaszki miażdżycowej i powstawania zakrzepów. Dodatkowo stosowana bywa w przetwórstwie mięsa i browarnictwie. Bromelaina może być jednak alergenem wywołującym różne reakcje, w tym pokrzywki, obrzęk naczynioruchowy, a nawet napady duszności. Ananas zawiera także profilinę, która w wyniku reakcji krzyżowych może wywoływać alergiczny nieżyt nosa $[4,5]$.

Jak wspomniano, ananas jest źródłem polifenoli, flawonoidów, witamin i beta-karotenu. Związki te są w większości zaliczane do przeciwutleniaczy i biorą udział w procesach obronnych organizmu, chroniąc go pośrednio przed negatywnymi skutkami promieniowania ultrafioletowego lub patogenami. Ich głównym zadaniem jest jednak minimalizowanie destrukcyjnego działania reaktywnych form tlenu na organizm i efektów występowania zjawiska stresu oksydacyjnego. Udowodniono, że odpowiednia podaż antyoksydantów zmniejsza ryzyko rozwoju chorób nowotworowych, sercowo-naczyniowych, cukrzycy, a także osteoporozy i chorób neurodegeneracyjnych, toteż coraz więcej uwagi naukowcy skupiają na potencjalnych naturalnych źródłach przeciwutleniaczy $[9,10,11]$.

Celem badań była ocena aktywności przeciwutleniającej alkoholowych ekstraktów z poszczególnych części ananasa jadalnego oznaczona przy użyciu 3 metod służących do analizy badanych właściwości.

\section{MATERIA $K Y$ I METODY}

Do przeprowadzenia badań użyto odczynników o czystości do analizy, dostarczonych przez firmę Chempur (Piekary Śląskie) - kwas solny $36 \%$, kwas octowy 99,5\%, bezwodny węglan sodu i bezwodny octan sodu oraz firmę Sigma Aldrich (USA) kwas 6-hydroksy-2,5,7,8-tetrametylochromano-2-karboksylowy - troloks, 2,4,6-tripirydylo-S-triazyna (TPTZ) i 2,2-difenylo-1-pikrylohydrazyl (DPPH). Wykorzystano także odczynnik Folina-Ciocalteu, chlorek żelaza(III) heksahydrat, siarczan(VI) żelaza(II) heptahydrat oraz kwas galusowy (GA) produkcji Merck (Niemcy).

Materiał badawczy stanowił owocostan ananasa jadalnego wraz z liśćmi przykwiatowymi, zakupiony w jednym z hipermarketów w Szczecinie. Wyodrębniono z niego miąższ, okrywę i liście. Do uzyskania 5\% ekstraktów jako rozpuszczalników użyto alkoholi: etylowego w stężeniu 70\% (v/v) i 96\% (v/v) oraz metylowego (99,8\% v/v). Tak przygotowane próby poddano działaniu ultradźwięków o częstotliwości $40 \mathrm{kHz}$ przez 15, 30 i 60 min. Otrzymane wyciągi przechowywano do czasu analizy, w temperaturze pokojowej, bez dostępu światła.

Do oceny właściwości przeciwutleniających ekstraktów z surowców wykorzystano metody: DPPH, oznaczania zdolności redukowania jonów żelaza (FRAP) i Folina-Ciocalteu (F-C). Pierwsza z nich opiera się na redukcji rodnika DPPH i jest jedną z częściej wykorzystywanych w tego typu analizach. W badaniach własnych wykorzystano nieznacznie zmodyfikowany sposób postępowania zaproponowany przez Abderrahima i wsp., Molyneuxa, Apaka i wsp. oraz Regulską i Samsonowicz $[12,13,14,15]$. Pomiaru absorbancji dokonano przy długości fali równej $517 \mathrm{~nm}$, w kuwetach $1 \mathrm{~cm}$, względem etanolu, korzystając ze spektrofotometru Spectroquant Pharo 300, Merck. Roztwór roboczy uzyskano w wyniku rozpuszczenia 0,012 g rodnika DPPH w $100 \mathrm{~cm}^{3} 70 \%$ (v/v) etanolu, mieszając przez 60 min na mieszadle magnetycznym. Następnie rozcieńczono go etanolem do ustalenia absorbancji w zakresie 1,000-1,020. Do $2500 \mu \mathrm{L}$ tak otrzymanego roztworu rodnika dodano $132 \mu \mathrm{L}$ badanego ekstraktu i po wstrząśnięciu inkubowano przez 10 min w temperaturze pokojowej. Po upływie tego czasu dokonano pomiaru absorbancji próbek. Otrzymane wartości wykorzystano do wyznaczenia zdolności zmiatania wolnych rodników (radical scavenging activity - RSA), korzystając ze wzoru:

$$
R S A[\%]=\left(1-\frac{A_{p}}{A_{0}}\right) \cdot 100 \%
$$

przy czym $A_{\mathrm{p}}$ oznacza absorbancję próby badanej, natomiast $A_{\mathrm{o}}$ absorbancję próby kontrolnej. Otrzymane wyniki porównano $\mathrm{z}$ aktywnościami etanolowego roztworu troloksu o znanym stężeniu, wyznaczając w ten sposób równoważne stężenia tego antyoksydantu, jakim odpowiadają aktywności badanych ekstraktów (wyrażone w mg troloksu/g surowca).

Do oceny zdolności do redukcji jonów żelaza $\mathrm{Fe}^{3+} \mathrm{z}$ kompleksu z TPTZ zastosowano metodę FRAP, nieznacznie zmodyfikowaną w porównaniu z metodyką zaproponowaną przez Apaka i wsp., Regulską i Samsonowicz oraz Cybul i Nowak $[14,15,16]$. Przygotowano $10 \mathrm{mmol} / \mathrm{dm}^{3}$ roztwór, rozpuszczając 0,0781 g TPTZ w $25 \mathrm{~cm}^{3}$ kwasu solnego o stężeniu $40 \mathrm{mmol} / \mathrm{dm}^{3}$. Sporządzono również roztwór $\mathrm{FeCl}_{3}$ o stężeniu $20 \mathrm{mmol} / \mathrm{dm}^{3}$ poprzez rozpuszczenie 0,1353 g chlorku żelaza(III) heksahydrat w $25 \mathrm{~cm}^{3}$ wody destylowanej. Do wykonania 
omawianych oznaczeń posłużył również bufor octanowy o pH 3,6, uzyskany poprzez zmieszanie $0,3 \mathrm{mmol} / \mathrm{dm}^{3}$ roztworów $\mathrm{CH}_{3} \mathrm{COONa}$ i $\mathrm{CH}_{3} \mathrm{COOH}$, do otrzymania wyznaczonej wartości odczynu pH. Następnie zmieszano 10 obj. buforu octanowego, 1 obj. roztworu TPTZ i 1 obj. roztworu $\mathrm{FeCl}_{3}$, uzyskując w ten sposób roztwór roboczy. Do $2500 \mu \mathrm{L}$ powyższego roztworu dodawano $87 \mu \mathrm{L}$ badanego wyciągu i inkubowano przez $15 \mathrm{~min}$ w temperaturze pokojowej. Pomiary absorbancji badanych prób przeprowadzono przy długości fali $593 \mathrm{~nm}$ względem buforu octanowego. Wyniki odniesiono do stężeń substancji wzorcowej, którą w tym przypadku był roztwór siarczanu(VI) żelaza(II). Oznaczono w ten sposób zdolność redukcji jonów żelaza wyrażoną w $\mathrm{mg} \mathrm{FeSO}_{4} / \mathrm{g}$ surowca.

Oceniono również całkowitą zawartość polifenoli metodą F-C, korzystając z nieznacznie zmodyfikowanej wersji opisanej przez Apaka i wsp. oraz Tana i wsp. [14, 15, 16, 17]. Opiera się ona na odwracalnej reakcji redukcji zawartego w odczynniku F-C molibdenu(VI) do molibdenu(V). Przed przeprowadzeniem pomiarów roztwór wspomnianego odczynnika rozcieńczono 10-krotnie wodą destylowaną i pozostawiono w ciemności na godzinę. Sporządzono także $5 \mathrm{mmol} / \mathrm{dm}^{3}$ wodny roztwór węglanu sodu. Następnie do $2500 \mu \mathrm{L}$ roztworu $\mathrm{Na}_{2} \mathrm{CO}_{3}$ dodawano kolejno $150 \mu \mathrm{L}$ próbki badanej i $139 \mu \mathrm{L}$ rozcieńczonego odczynnika F-C. Absorbancję próbek mierzono po trwającej 15 min inkubacji w temperaturze pokojowej. Pomiarów dokonano przy długości fali $750 \mathrm{~nm}$ względem wody. Zawartość polifenoli wyrażono w mg GA/g surowca.

Z każdego ekstraktu sporządzono 3 próby, które następnie poddano analizie. Wyniki przedstawiono jako średnie arytmetyczne \pm odchylenie standardowe. Analizy statystycznej otrzymanych wyników dokonano jednoczynnikowym testem ANOVA, natomiast różnice międzygrupowe oceniono testem Tuckeya ( $\mathrm{p}=0,05)$, grupując uzyskane wyniki względem użytego rozpuszczalnika. Wyznaczono również korelację pomiędzy wynikami uzyskanymi przy zastosowaniu metod FRAP i DPPH. Do oceny statystycznej otrzymanych wyników posłużył program Statistica 12 (Statsoft).

\section{WYNIKI}

Wyniki badań przedstawiono na rycinach 1-4 oraz w tabeli 1. Uwzględniono podział na poszczególne części roślin obejmujący miąższ, okrywę i liście ananasa jadalnego oraz rodzaj użytego rozpuszczalnika. Wzięto również pod uwagę czasy ekstrakcji wspomaganej ultradźwiękami, której poddane były badane próby.

Na rycinie 1 i w tabeli 1 przedstawiono wyniki badań przeprowadzonych z użyciem metody opartej na reakcji redukcji rodnika DPPH. W tabeli 1 zebrano wartości aktywności antyoksydacyjnej wyciągów z poszczególnych części ananasa w badanych rozpuszczalnikach, wyrażonych jako RSA (\%), natomiast na rycinie 1 - w postaci równoważników troloksu. Wszystkie badane ekstrakty wykazywały działanie przeciwutleniające. Mieściło się ono w granicach od 4,48 $\pm 0,50$ do 11,90 $\pm 1,06 \%$ RSA oznaczonego metodą DPPH (tab. 1), co odpowiadało stężeniu
TABELA 1. Właściwości przeciwutleniające ekstraktów z poszczególnych części ananasa jadalnego oznaczone metodą z użyciem odczynnika 2,2-difenylo-1pikrylohydrazylu i wyrażone jako zdolność zmiatania wolnych rodników - RSA (średnia \pm odchylenie standardowe)

Rozpuszczalnik użyty do ekstrakcji

\begin{tabular}{cccc}
\multirow{2}{*}{$\begin{array}{c}\text { Surowiec i czas } \\
\text { ekstrakcji }\end{array}$} & $\begin{array}{c}\text { etanol 70\% } \\
(\mathbf{v} / \mathbf{v})\end{array}$ & $\begin{array}{c}\text { etanol } 96 \% \\
(\mathbf{v} / \mathbf{v})\end{array}$ & $\begin{array}{c}\text { metanol } 99,8 \% \\
(\mathbf{v} / \mathbf{v})\end{array}$ \\
\cline { 2 - 4 } RSA $(\%)$ \\
\hline Miąższ
\end{tabular}

Wartości oznaczone literami a, b i c różnią się istotnie statystycznie w obrębie danego rozpuszczalnika. Poziom istotności: $\alpha=0,05 ; n=3$

troloksu w zakresie od 0,14 $\pm 0,07$ do 0,49 $\pm 0,05 \mathrm{mg}$ troloksu/g surowca (ryc. 1). Najwyższy wynik uzyskano w przypadku metanolowego wyciągu z okrywy ananasa ekstrahowanej przez $60 \mathrm{~min}-11,90 \pm 1,06 \%$, co odpowiada 0,49 $\pm 0,05 \mathrm{mg}$ troloksu/g surowca. Podobne wartości zaobserwowano dla prób z tej części surowca, ekstrahowanych przy użyciu etanolu 70\% (v/v) - 11,56 $\pm 0,79 \%$. Biorąc pod uwagę badane części ananasa, najwyższe aktywności stwierdzono dla ekstraktu z miąższu $11,34 \pm 1,01 \%$ oraz ekstraktu z liści $-9,92 \pm 1,22 \%$, otrzymanych w wyniku działania ultradźwięków przez $60 \mathrm{~min}$, przy czym w obu przypadkach rozpuszczalnikiem był 99,8\% (v/v) metanol. Najniższe wartości przy użyciu tej metody wykazywały wyciągi z liści ananasa jadalnego: 4,48 $\pm 0,50 \%$ w 70\% (v/v) etanolu, ekstrahowane przez 60 min oraz 5,95 $\pm 0,91 \%$ - w 96\% (v/v) etanolu przez $30 \mathrm{~min}$, co odpowiadało 0,14 $\pm 0,07$ i 0,21 $\pm 0,09 \mathrm{mg}$ troloksu/g surowca. Należy zaznaczyć, że w przypadku tej techniki ekstrakty z poszczególnych części ananasa jadalnego charakteryzowały się niskimi średnimi wartościami RSA, przy czym najniższymi z liści - średnio 7,29\%, kolejno z miąższu średnio 8,72\% i z okrywy - 9,00\%.

Wyniki pomiarów zdolności do redukcji jonów żelaza, oznaczonych metodą FRAP, przedstawiono na rycinie 2. Zarówno najwyższą, jak i najniższą wartość w tej grupie badanych wyciągów wykazały próby, w których ekstrahentem był 70\% (v/v) etanol. Podobnie jak w przypadku metody DPPH ekstrakt z okrywy ananasa, wytrawiany przez $60 \mathrm{~min}$, wykazywał największe właściwości - 2,76 $\pm 0,36 \mathrm{mg} \mathrm{FeSO}_{4} / \mathrm{g}$ surowca. Również wysokie właściwości redukcyjne stwierdzono dla metanolowych ekstraktów poddawanych działaniu ultradźwięków przez 60 min - 2,68 £0,15 w przypadku wyciągu z miąższu i 2,55 £0,15 z okrywy. Można zauważyć, że - podobnie jak w przypadku poprzedniej metody - najsłabszymi 


\section{DPPH}

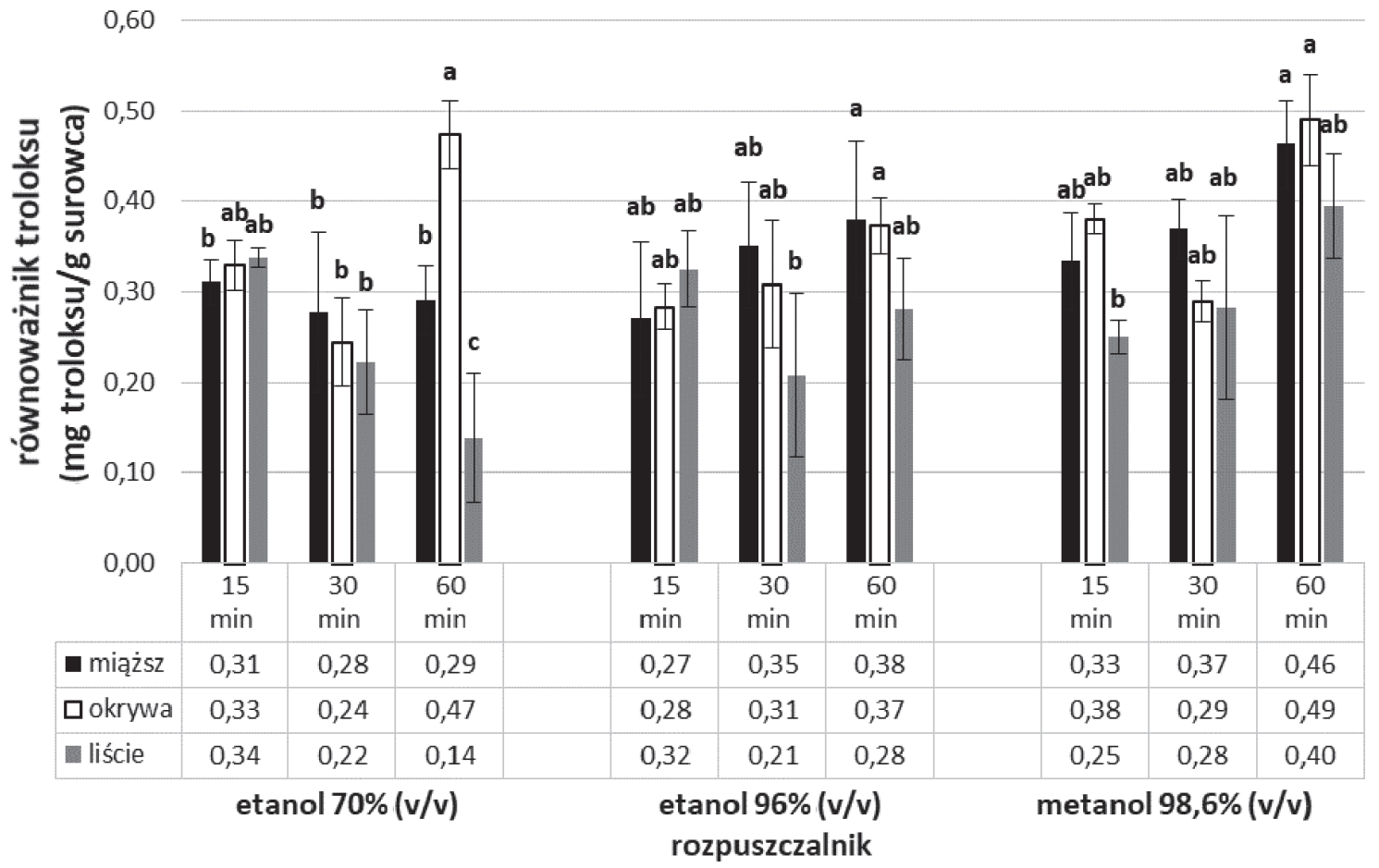

Linie pionowe oznaczają odchylenie standardowe. Wartości oznaczone różnymi literami odpowiednio dla każdego rozpuszczalnika różnią się istotnie statystycznie $(n=3 ; \alpha=0,05)$.

RYCINA 1. Średnie wartości równoważników troloksu (mg troloksu/g surowca) uzyskane metodą z użyciem odczynnika

2,2-difenylo-1-pikrylohydrazylu (DPPH), odpowiadające aktywności antyoksydacyjnej poszczególnych ekstraktów z ananasa jadalnego

FRAP

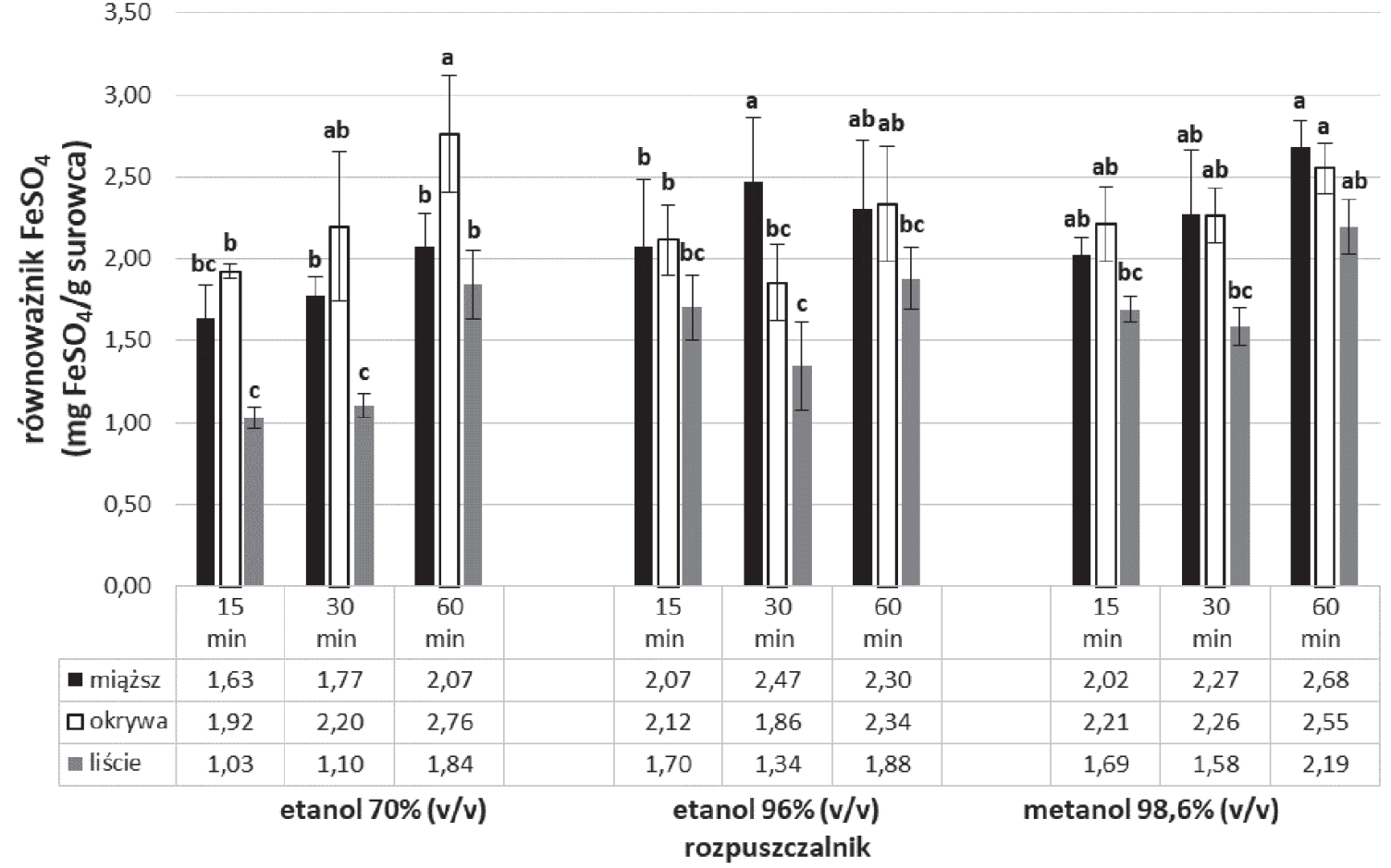

Linie pionowe oznaczają odchylenie standardowe. Wartości oznaczone różnymi literami odpowiednio dla każdego rozpuszczalnika różnią się istotnie statystycznie $(n=3 ; \alpha=0,05)$.

RYCINA 2. Średnie wartości równoważników $\mathrm{FeSO}_{4}$ (mg FeSO $_{4} / g$ surowca) uzyskane przy użyciu metody oznaczania zdolności redukowania jonów żelaza (FRAP), odpowiadające aktywności antyoksydacyjnej poszczególnych ekstraktów z ananasa jadalnego 
właściwościami charakteryzowały się liście z ananasa, osiągając wartości odpowiednio 1,03 $\pm 0,06$ i 1,10 $\pm 0,07 \mathrm{mg} \mathrm{FeSO}_{4} / \mathrm{g}$ surowca dla wyciągów w 70\% (v/v) etanolu ekstrahowanych przez 15 i 30 min. Należy dodać, że obserwowano istotną statystycznie korelację pomiędzy wynikami otrzymanymi przy użyciu metody DPPH i FRAP ( $\mathrm{r}=0,6556 ; \mathrm{p}=0,0002)$ - rycina 3 .

Nieco odmiennie kształtują się wyniki badań całkowitej zawartości polifenoli, oznaczone metodą F-C, wyrażone jako równoważniki stężeń substancji wzorcowej, czyli GA (ryc. 4). Wartości te mieściły się w zakresie od 0,24 $\pm 0,02$

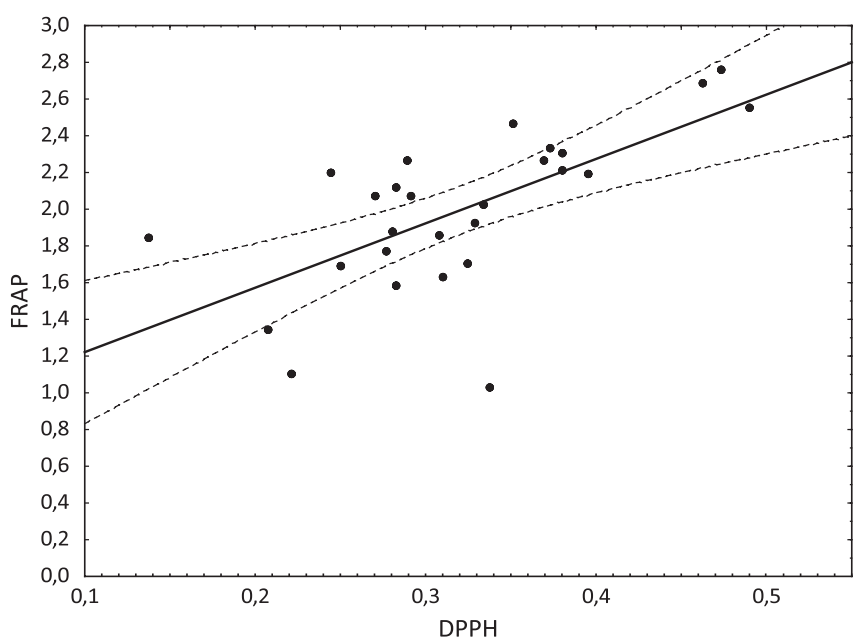

RYCINA 3. Korelacja pomiędzy wartościami aktywności antyoksydacyjnej uzyskanymi metodą z użyciem odczynnika 2,2-difenylo-1-pikrylohydrazylu (DPPH) oraz metodą oznaczania zdolności redukowania jonów żelaza (FRAP) dla wyciągów z miąższu ekstrahowanych w 96\% (v/v) etanolu, do 1,90 $\pm 0,18 \mathrm{mg} \mathrm{GA} / \mathrm{g}$ surowca dla otrzymanych w 70\% (v/v) alkoholu. Najbardziej wartościowe pod względem badanych własności okazały się próby z miąższu, wytrawiane przez 15 i $30 \mathrm{~min}$, osiągające wyniki na poziomie 1,80 $\pm 0,05$ i 1,90 $\pm 0,18 \mathrm{mg} \mathrm{GA} / \mathrm{g}$ surowca, natomiast najmniej - ekstrakty z tej samej części rośliny, w których rozpuszczalnikiem był stężony etanol. Podobnie niskie wartości - 0,27 £0,04 mg GA/g surowca otrzymano w przypadku jednego z metanolowych ekstraktów z liści.

\section{DYSKUSJA}

W przedstawionych badaniach porównano aktywność antyoksydacyjną wyciągów alkoholowych z różnych części ananasa jadalnego. Analizie poddano miąższ, okrywę oraz liście przykwiatowe. Wszystkie części owocu były ekstrahowane w formie świeżej, przy wykorzystaniu łaźni ultradźwiękowej, z zastosowaniem jako rozpuszczalników alkoholu etylowego w stężeniu 70\% i 96\% oraz metylowego (99,8\%). W przeprowadzonym doświadczeniu wszystkie części badanego owocu charakteryzowały się niezbyt wysoką aktywnością przeciwutleniającą.

W przypadku metody opartej na redukcji rodnika DPPH największą aktywnością antyoksydacyjną cechowały się ekstrakty z okrywy owocu ananasa, a najniższą - z liści przykwiatowych. Wyniki badań wskazują, że wszystkie części ananasa jadalnego

\section{Folin-Ciocalteu}

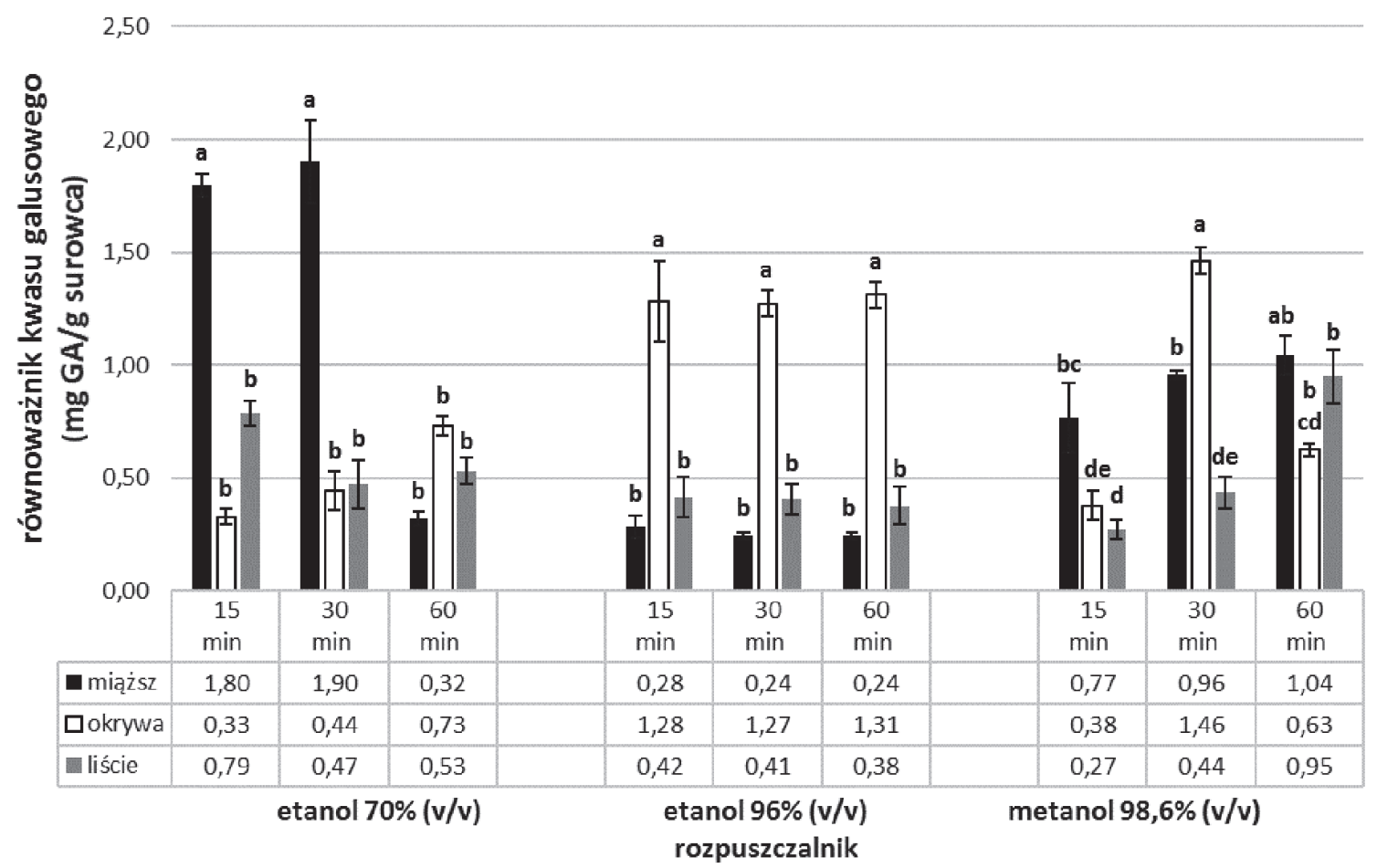

Linie pionowe oznaczają odchylenie standardowe. Wartości oznaczone różnymi literami odpowiednio dla każdego rozpuszczalnika różnią się istotnie statystycznie $(n=3 ; \alpha=0,05)$.

RYCINA 4. Średnie wartości całkowitej zawartości polifenoli w badanych ekstraktach z ananasa jadalnego wyrażone jako równoważniki kwasu galusowego (mg GA/g surowca), oznaczone metodą Folina-Ciocalteu 
wykazywały niezbyt wysoki stopień zmiatania wolnych rodników, najwyższy - 11,91\% w przypadku miąższu ekstrahowanego w metanolu przez 60 min (tab. 1). Nieco wyższe wyniki uzyskali Montero-Calderón i wsp., którzy wykazali aktywność antyoksydacyjną miąższu ananasa na poziomie $42-49 \%$ w zależności od części owocu. W badaniach tych analizowano górną, środkową i dolną część świeżego owocu [18]. Porównywalne do poprzedników wartości uzyskali Zang i wsp., gdyż w przeprowadzonych przez nich badaniach ekstrakty z ananasa dezaktywowały od $37,74 \pm 1,90$ do $43,49 \pm 4,34 \%$ rodnika DPPH, co umiejscawia ananasa w grupie owoców o średnich właściwościach przeciwutleniających. Należy dodać, że znacznie wyższymi charakteryzowały się morwa, czarna i zielona śliwka, ciemne winogrona, truskawki i owoce kiwi [19].

W badaniach własnych, przeprowadzonych przy użyciu metody FRAP, wykazano zdolność redukcyjną mieszczącą się w granicach od 1,03 $\pm 0,06$ do 2,76 $\pm 0,36 \mathrm{mg} \mathrm{FeSO}_{4} /$ g surowca (ryc. 2), natomiast przy ocenie ogólnej zawartości polifenoli uzyskane wartości wahały się w granicach od 1,90 $\pm 0,18 \mathrm{w}$ przypadku ekstraktów przygotowanych z miąższu w 70\% etanolu (30 $\mathrm{min}$ ) do zaledwie 0,24 $\pm 0,02 \mathrm{mg} \mathrm{GA} / \mathrm{g}$ surowca dla ekstraktów z tej części rośliny uzyskanych przy użyciu 96\% (v/v) etanolu (30 i $60 \mathrm{~min}$ ) - rycina 4. Sun i wsp. badali również aktywność przeciwutleniającą wyciągów ze znanych owoców, w tym ananasa jadalnego. Wyniki uzyskane przez nich przy użyciu metody Folina-Ciocalteu, porównywalne z otrzymanymi w badaniu własnym, świadczą o niskiej zawartości polifenoli w owocu ananasa $(40,4 \pm 1,0 \mathrm{mg} \mathrm{GA} / 100$ g surowca), gdyż znacznie wyższe wartości uzyskano dla żurawiny, jabłek, czerwonych winogron i truskawek (nawet do 507,0 $\pm 0,21 \mathrm{mg}$ GA/100 g). Autorzy oceniali także aktywność antyoksydacyjną owoców przy użyciu metody oznaczania całkowitej zdolności wychwytywania rodników tlenowych, w przypadku której jadalna część omawianej rośliny uzyskała istotne statystycznie najniższe wyniki spośród 11 badanych surowców [20].

Jak wskazano we wcześniej przeprowadzonych badaniach, ważnym czynnikiem mogącym wpływać na aktywność przeciwutleniającą wyciągów, jest sposób ekstrakcji, w tym typ użytego rozpuszczalnika oraz jego stężenie [21, 22]. Analiza otrzymanych wyników wskazuje na przydatność 70\% (v/v) etanolu do ekstrahowania składników badanych owoców o działaniu przeciwutleniającym, gdyż w przypadku każdej ze stosowanych metod jednymi z najwyższych aktywności charakteryzowały się ekstrakty, do sporządzenia których użyto tego rozpuszczalnika. Nie stwierdzono podobnej prawidłowości w przypadku 96\% (v/v) etanolu, co może sugerować, że niewielka ilość wody w tym rozpuszczalniku może okazać się niewystarczająca do ekstrakcji związków o badanych właściwościach, najczęściej o charakterze polarnym. Wyniki uzyskane w tej grupie ekstraktów mieściły się między wartościami najwyższymi a najniższymi w przypadku metod DPPH i FRAP, nie przyjmując jednak wartości skrajnych. Metanol wydaje się rozpuszczalnikiem mało przydatnym do ekstrakcji substancji spożywczych z uwagi na toksyczne działanie, choć w przypadku metody DPPH największą wartość RSA (\%) wykazał metanolowy ekstrakt z okrywy ananasa. Podobną prawidłowość zaobserwowali Martínez i wsp., którzy badali produkty odpadowe owoców, w tym okrywę ananasa, wykazując, że ekstrakty metanolowo-acetonowe mają wyższą aktywność antyoksydacyjną, badaną przy użyciu metod DPPH, FRAP i ABTS, niż wyciągi etanolowe [23]. Malik i wsp. analizowali właściwości soków z owoców południowych zarówno dostępnych na rynku, jak i własnej produkcji. Sok z ananasa charakteryzował się najwyższą aktywnością przeciwutleniającą wyrażoną jako równoważnik troloksu $\left(731,73 \mathrm{mmol} / \mathrm{dm}^{3}\right)$ w grupie soków domowych i jednocześnie najniższą zawartością flawonoli spośród badanych prób. Dodatkowo autorzy stwierdzili, że jest on cennym źródłem potasu, magnezu i wapnia [24].

Przy wykonywaniu badań aktywności przeciwutleniającej czas ekstrakcji wydaje się mieć istotne znaczenie, gdyż w badaniach własnych większość ekstraktów charakteryzujących się najwyższym potencjałem antyoksydacyjnym została pozyskana podczas 60 min działania ultradźwięków na surowiec. Nie można jednak wysnuć analogicznego wniosku dla najkrótszego czasu ekstrakcji. Rodríguez i wsp. sugerują, że użycie ultradźwięków w celu ekstrahowania ananasa w różny sposób wpływa na zawarte w nim bioaktywne związki. Autorzy wnoszą, że może ono zwiększać stężenie niektórych składników w porównaniu z próbami niepoddanymi działaniu ultradźwięków, w tym witamin z grupy B, flawonoidów i kwasu jabłkowego, a z drugiej strony obniżeniu może ulegać stężenie witaminy C, polifenoli i kwasu cytrynowego. Ponadto z ich badań wynika, że próbki uzyskane z suszonego surowca wykazują zdecydowanie wyższe wartości w porównaniu z próbkami ze świeżego ananasa [25].

Podsumowując, należy stwierdzić, że w przypadku dwóch z trzech zastosowanych metod oceny aktywności przeciwutleniającej wyciągi uzyskane z okrywy ananasa jadalnego wykazywały najwyższe wartości tego parametru, niższe natomiast próby sporządzone z miąższu, a najniższe z liści. Przy oznaczeniu metodą F-C największą zawartością polifenoli charakteryzował się miąższ tej rośliny.

\section{WNIOSKI}

1. Miąższ owocu, jego okrywa i liście przykwiatowe ananasa jadalnego charakteryzowały się aktywnością przeciwutleniającą, mierzoną za pomocą metod DPPH, FRAP i F-C.

2. Najwyższy potencjał antyoksydacyjny wykazywały ekstrakty z okrywy oraz miąższu ananasa, w zależności od użytej metody analiz.

3. Działanie przeciwutleniające otrzymanych wyciągów było zależne zarówno od części owocu, z której pozyskano ekstrakty, jak i czasu ekstrakcji oraz rodzaju użytego rozpuszczalnika - najbardziej wartościowe pod tym względem okazały się wyciągi z okrywy ananasa ekstrahowane w 70\% (v/v) etanolu przez $60 \mathrm{~min}$.

4. Owoce ananasa jadalnego wykazują umiarkowaną aktywność antyoksydacyjną, jednak z uwagi na ich inne korzystne właściwości i obecność cennych składników aktywnych mogą być przydatne do utrzymania dobrego stanu 
zdrowia, a także wspomagać eliminowanie negatywnych skutków stresu oksydacyjnego.

\section{PIŚMIENNICTWO}

1. Jędrzejko K, Kowalczyk B, Balcer B. Rośliny kosmetyczne. Katowice: Wyd. SUM; 2007.p. 72.

2. Da Silva DI, Nogueira GD, Duzzioni AG, Barrozo MA. Changes of antioxidant constituents in pineapple (Ananas comosus) residue during drying process. Ind Crops Prod 2013;50:557-62.

3. Zielonka-Brzezicka J, Synowiec L, Nowak A, Klimowicz A. Wybrane owoce jako źródło cennych składników stosowanych w kosmetologii. Post Fitoter 2017;18(2):126-31. doi: 10.25121/PF.2017.16.2.126.

4. Ukleja-Sokołowska N, Gawrońska-Ukleja E, Tykwińska M, Bartuzi Z. Alergia na owoce egzotyczne. Alerg Astma Immun 2014;19(8):16-20.

5. Bhattacharyya BK. Bromelain: an overview. Nat Prod Rad 2008;7: 359-63.

6. Ahmad N, Sharma S. Green synthesis of silver nanoparticles using extracts of Ananas comosus. Green Sustain Chem 2012;2:141-7. doi: 10.4236/ gsc.2012.24020.

7. Ketnawa S, Rawdkuen S, Chaiwut P. Two phase partitioning and collagen hydrolysis of bromelain from pineapple peel Nang Lae cultivar. Biochem Eng J 2010;52(2-3):205-11. 10.1016/j.bej.2010.08.012.

8. Rathnavelu V, Alitheen NB, Sohila S, Kanagesan S, Ramesh R. Potential role of bromelain in clinical and therapeutic applications. Biomed Rep 2016;5(3):283-8. doi: 10.3892/br.2016.720.

9. Muzykiewicz A, Zielonka-Brzezicka J, Klimowicz A, Florkowska K. Jarząb pospolity (Sorbus aucuparia L.) jako źródło składników o potencjalnym działaniu antyoksydacyjnym - porównanie właściwości przeciwutleniających ekstraktów z liści, kwiatów i owoców. Probl Hig Epidemiol 2017;98(2):125-32.

10. Nowak A, Zielonka J, Turek M., Klimowicz A. Wpływ przeciwutleniaczy zawartych w owocach na proces fotostarzenia się skóry. Post Fitoter 2014;15(2):94-9.

11. Pandey KB, Rizvi SI. Plant polyphenols as dietary antioxidants in human health and disease. Oxid Med Cell Longev 2009;2(5):270-8. doi: 10.4161/ oxim.2.5.9498.

12. Abderrahim F, Arribas SM, Gonzalez MC, Condezo-Hoyos L. Rapid highthroughput assay to assess scavenging capacity index using DPPH. Food Chem 2013;141(2):788-94. doi: 10.1016/j.foodchem.2013.04.055.

13. Molyneux P. The use of stable free radical diphenylpicrylhydrazyl (DPPH) for estimating antioxidant activity. Songklanakarin J Sci Technol 2004;26(2):211-9.
14. Apak R, Özyürek M, Güçlü K, Çapanoğlu E. Antioxidant activity/capacity measurement. 1. Classification, physicochemical principles, mechanisms, and electron transfer (ET)-based assays. J Agr Food Chem 2016;64(5):9971027. doi: 10.1021/acs.jafc.5b04739.

15. Regulska E, Samsonowicz M. Ekstrakty ziołowe w aspekcie zawartości związków polifenolowych i aktywności przeciwutleniającej. In: Tarko W, Duda-Chodak A, Witczak M, Najgebauer-Lejko D, editors. Właściwości produktów i surowców żywnościowych. Kraków: Polskie Towarzystwo Technologów Żywności; 2014. p. 227-37.

16. Cybul M, Nowak R. Przegląd metod stosowanych w analizie właściwości antyoksydacyjnych wyciągów roślinnych. Herba Pol 2008;54(1):68-78.

17. Tan YS, Baskaran A, Nallathamby N, Chua KH, Kuppusamy UR, Sabaratnam V. Influence of customized cooking methods on the phenolic contents and antioxidant activities of selected species of oyster mushrooms (Pleurotus spp.). J Food Sci Technol 2015;52(5):3058-64. doi: 10.1007/ s13197-014-1332-8.

18. Montero-Calderón M, Rojas-Graű M, Martín-Belloso O. Mechanical and chemical properties of Gold cultivar pineapple flesh (Ananas comosus). Eur Food Res Technol 2010;230(4):675-86. doi: 10.1007/s00217-009-1207-9.

19. Zang S, Tian S, Jiang J, Han D, Yu X, Wang K, et al. Determination of antioxidant capacity of diverse fruits by electron spin resonance (ESR) and UV-Vis spectrometries. Food Chem 2017;221:1221-5. doi: 10.1016/j.foodchem.2016.11.036.

20. Sun J, Chu YF, Wu X, Liu RH. Antioxidant and antiproliferative activities of common fruits. J Agric Food Chem 2002;50(25):7449-54. doi: 10.1021/ jf0207530.

21. Nowak A, Zielonka-Brzezicka J, Pechaiko D, Tkacz M, Klimowicz A. Ocena właściwości antyoksydacyjnych liści Ginkgo biloba L. po zakończeniu wegetacji. Pomeranian J Life Sci 2017;63(1):9-15. doi: 10.21164/pomjlifesci.222.

22. Zielonka-Brzezicka J, Nowak A, Zielińska M, Klimowicz A. Porównanie właściwości przeciwutleniających wybranych części maliny właściwej (Rubus idaeus) i jeżyny europejskiej (Rubus fruticosus). Pomeranian J Life Sci 2016;62(4):52-9. doi: 10.21164/pomjlifesci.269.

23. Martínez R, Torres P, Meneses MA, Figueroa JG, Pérez-Álvarez JA, ViudaMartos M. Chemical, technological and in vitro antioxidant properties of mango, guava, pineapple and passion fruit dietary fibre concentrate. Food Chem 2012;135(3):1520-6. doi: 10.1016/j.foodchem.2012.05.057.

24. Malik A, Pytka M, Latoch A, Targoński Z, Giza W. Wybrane związki bioaktywne w owocach południowych i otrzymanych z nich sokach. In: Karwowska M, Gustaw W, editors. Trendy w żywieniu człowieka. Kraków: Polskie Towarzystwo Technologów Żywności; 2015. p. 187-201.

25. Rodríguez Ó, Gomes W, Rodrigues S, Fernandes FA. Effect of acoustically assisted treatments on vitamins, antioxidant activity, organic acids and drying kinetics of pineapple. Ultrason Sonochem 2017;35:92-102. doi: 10.1016/j.ultsonch.2016.09.006. 